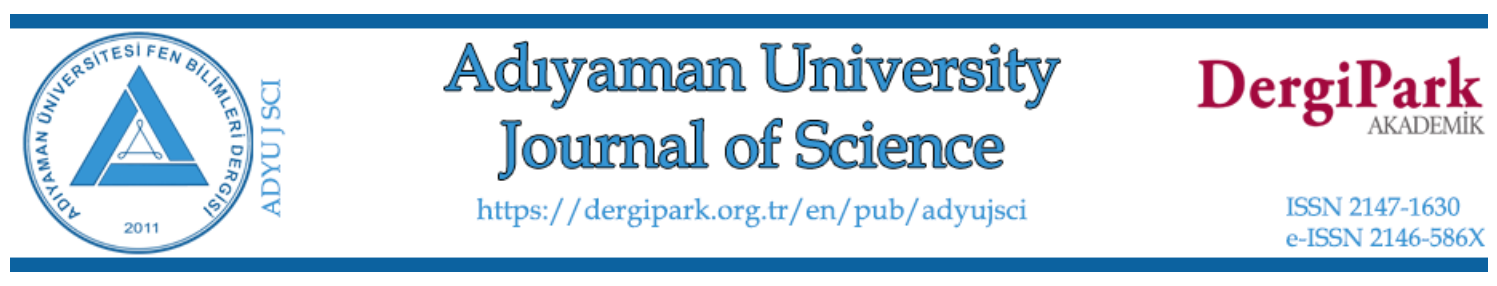

\title{
Comparing Different Approaches to Form Cobalt Oxide Layer on CoPt
}

\section{Nanoparticles}

\author{
Dogan $\mathrm{KAYA}^{1, *}$, Idris ADANUR ${ }^{2}$, Mustafa $\mathrm{AKYOL}^{3}$, Faruk KARADAG ${ }^{2}, \mathrm{Ahmet}_{\text {EKICIBIL }}^{2}$ \\ ${ }^{I}$ Cukurova University, Vocational School of Adana, Department of Electronics and Automation, Adana, \\ Turkey \\ dogankaya@cu.edu.tr, ORCID: 0000-0002-6313-7501 \\ ${ }^{2}$ Cukurova University, Faculty of Art and Sciences, Department of Physics, Adana, Turkey \\ adanuridris@gmail.com,ORCID:0000-0002-0160-5074 \\ ${ }^{3}$ Adana Alparslan Turkes Science and Technology University, Faculty of Engineering, Materials \\ Engineering Department, Adana, Turkey \\ makyol@atu.edu.tr, ORCID: 0000-0001-8584-0620 \\ ${ }^{2}$ Cukurova University, Faculty of Art and Sciences, Department of Physics, Adana, Turkey \\ fkaradag@cu.edu.tr, ORCID: 0000-0001-7862-9085 \\ ${ }^{2}$ Cukurova University, Faculty of Art and Sciences, Department of Physics, Adana, Turkey \\ ahmetcan@cu.edu.tr, ORCID: 0000-0003-3071-0444
}

\section{Abstract}

We have studied the effect of preparation methods, under argon gas and in the air environment, on the cobalt oxide formation of CoPt nanoparticles by the polyol process. The formation of cobalt oxide for both samples was investigated by the x-ray diffraction (XRD) method and cobalt oxide peaks are observed in the air prepared sample. Rietveld refinement analyses revealed that all samples exhibit a chemically distorted cubic crystal structure. The average particle size was determined $<8 \mathrm{~nm}$ by scanning electron microscopy (SEM) and energydispersive x-ray spectroscopy (EDS) was revealed the chemical compositions with possible oxygen formation in the structure. The blocking temperature is reduced to $28 \mathrm{~K}$ in the air prepared sample due to cobalt oxide formation. The hysteresis gap disappeared above the blocking temperature and no saturation is observed up to $\pm 5 \mathrm{~T}$ external field due to the system switching 
from ferromagnetic state to paramagnetic state. Similarly, the coercive field was decreased from $1021 \mathrm{Oe}$ to zero with increasing the temperature from $5 \mathrm{~K}$ to $300 \mathrm{~K}$. The formations of the cobalt oxide layer did not interact with CoPt nanoparticles, therefore, the maximum exchange bias was observed about 93 Oe at $5 \mathrm{~K}$.

Keywords: CoPt NPs; Cobalt oxide formation; Polyol; XRD; SEM; PPMS.

\section{CoPt Nanoparçacıkların Üzerine Kobalt Oksit Tabakası Oluşturmada Farklı Yaklaşımların Karşılaştırılması}

\section{$\ddot{O} \mathbf{z}$}

Polyol yöntemi ile hazırlanan CoPt nanoparçackklarının üzerine oluşturulan kobalt oksit oluşumunun argon gazı ve hava ortamında etkilerini çalıştık. Her iki numune için kobalt oksit oluşumu, X-ışını kırınımı (XRD) yöntemi ile araştırıldı ve hava ile hazırlanan numunede kobalt oksit oluşumu gözlendi. Rietveld düzeltme analizleri, tüm numunelerin kimyasal olarak düzenli olmayan bir kübik kristal yapı sergilediğini ortaya çıkarmıştır. Ortalama parçacık boyutu, taramalı elektron mikroskopisi (SEM) ile $<8 \mathrm{~nm}$ olarak belirlendi ve $\mathrm{x}$-1şını enerji dağılımlı spektrometre (EDS) yapıda olası oksijen oluşumuna sahip kimyasal bileşimleri ortaya çıkardı. Hava ortamında hazırlanan numune ile kobalt oksit oluşumu nedeniyle bloke etme sıcaklığı $28 \mathrm{~K}$ sıcaklığa düşürülmüştür. Histeresis açıklığı engelleme sıcaklığının üzerinde kayboldu ve sistemin ferromanyetik durumdan paramanyetik duruma geçmesi nedeniyle $\pm 5 \mathrm{~T}$ dış alanda doygunluk manyetizasyonu gözlenmedi. Benzer şekilde, sıcaklığı 5 K'den 300 K'ne yükselterek zorlayıcı alan 1021 Oe'den sıfıra düşürüldü. Kobalt oksit tabakası oluşumları CoPt nanoparçacıkları ile etkileşime girmedi, bu nedenle maksimum değişim eğilimi $5 \mathrm{~K}$ 'de yaklaşık olarak 93 Oe gözlemlendi.

Anahtar Kelimeler: CoPt nanoparçacıklar; Kobalt oksit oluşumu; Polyol; XRD; SEM; PPMS.

\section{Introduction}

Magnetic nanoparticles (NPs) with size below $10 \mathrm{~nm}$ have attracted enormous interest for future device applications, such as, high density magnetic hard disk devices, permanent magnets, medical applications, etc. [1-3]. Although the small size leads to enhance physical and magnetic properties, superparamagnetic behaviour is an undesirable situation for recording media applications due to the thermal fluctuation and instability [4]. To govern the magnetism in ferromagnetic materials, such as $\mathrm{Fe}, \mathrm{Co}$, and $\mathrm{Ni}$, usually doping paramagnetic or diamagnetic metal atoms, Pt, $\mathrm{Pd}, \mathrm{Mn}, \mathrm{Au}, \mathrm{Ag}$, etc. are a preferred idea to reduce the size and desired level of 
magnetism in the sample [5]. Since Fe, Co, FePt, FePd, or CoPt nanoparticles are widely used for applications due to their chemical stability [6-10]. Controlling size, shape, and magnetism of these NPs need to focus further progresses.

Cobalt nanoparticles are widely preferred in technological applications due to its strong natural ferromagnetic order and chemical stability [11]. Particularly, chemically prepared CoPt NPs exhibits excellent magnetic properties and catalytic activities $[12,13]$ when the size reduced below $10 \mathrm{~nm}$. The formation of cobalt oxide $\left(\mathrm{CoO}, \mathrm{Co}_{2} \mathrm{O}_{3}\right.$, or $\left.\mathrm{Co}_{3} \mathrm{O}_{4}\right)$ on CoPt nanoparticles provides a chemical and thermal stability of magnetic application as well as in Li-ion batteries, optical devices, catalysts, gas and humidity sensors properties [14-16]. There are several methods which result in high-quality cobalt oxide formation on clusters by polyol process, solgel method, thermal composition, etc. [17-19] techniques are widely used for the synthesis of these NPs to enhance and control the magnetic properties of the NPs. Among them, polyol process provides more control on particle nucleation, growth, and agglomeration of metal NPs so that the particle size can be easily reduced below $10 \mathrm{~nm}$ and forming a shell on core structure is possible with two steps polyol process. When the antiferromagnetic nature of cobalt oxide interacts with ferromagnetic CoPt layer, exchange bias can emerge regarding with a small particle size of CoPt.

In this paper, we aimed to investigate the morphologic and magnetic properties of the twostep synthesis of cobalt oxide on CoPt nanoparticles under Ar gas and in the air environment by polyol process. After determined oxide formation in the samples with XRD spectrometry, Rietveld refinement provided the structural information in the samples. We have investigated magnetic properties as a function of temperature at zero-field cooled (ZFC) and field cooled (FC), besides as a function of applied external field up to $\pm 5 \mathrm{~T}$ at $5 \mathrm{~K}, 60 \mathrm{~K}$, and $300 \mathrm{~K}$. We showed that the magnetic properties below the blocking temperature are fairly large despite a striking change of magnetism at higher temperatures.

\section{Materials and Methods}

We conducted two-step processes to syntheses of cobalt oxide on CoPt NPs using polyol method. The first phase is preparing CoPt particles which is mixture of $0.2026 \mathrm{~g} \mathrm{Co}(\mathrm{acac})_{2}$ (Sigma-Aldrich $\geq 99.0 \%$ ), $0.3097 \mathrm{~g} \mathrm{Pt(acac)}$ (Sigma-Aldrich $\geq 97.0 \%$ ), and $6.4909 \mathrm{~g} \mathrm{1,2-}$ hexadecanediol (Sigma-Aldrich $\geq 90 \%$ ) with $60 \mathrm{ml}$ diethyl ether solution in a three-necked roundbottom flask fitted with a condenser at room temperature. We stirred for long enough under Ar gas flow to obtain a homogeneous mixture before adding $4.7824 \mathrm{~mL}$ oleic acid, and $4.9578 \mathrm{~mL}$ oleylamine surfactants. The mixture was heated to $200^{\circ} \mathrm{C}$ and waited for $20 \mathrm{~min}$ with continuous string. Following, the mixture was cooled to RT and hexane and ethanol washing centrifugation 
cycles were performed with $9000 \mathrm{rpm}$ for $10 \mathrm{~min}$. The second phase is forming a cobalt oxide layer on pre-prepared CoPt NPs using the same procedure. We conducted two different methods: (a) under Ar gas (CP-Ar) and (b) under air (CP-Air). Once, the dust CoPt sample is dried, 0.1025 $\mathrm{g} \mathrm{CoPt}$ and $0.2026 \mathrm{~g} \mathrm{Co}(\mathrm{acac})_{2}$ were mixed with $3.0228 \mathrm{~g}$ 1,2-hexadecanediol in $40 \mathrm{ml}$ diethyl ether. Then the mixture temperature was again elevated to $200{ }^{\circ} \mathrm{C}$ and waited for $20 \mathrm{~min}$.

X-ray powder diffraction (XRD) data were acquired at room temperature on a PANaylitical diffractometer with $\mathrm{Cu}-\mathrm{K} \alpha$ radiation $(\lambda=1.54 \AA)$ for the structural characterization of as-prepared NPs. FEI scanning electron microscopy (SEM) images are collected at $20 \mathrm{kV}$ to obtain the average particle size and the ratio of the NPs compositions were calculated from energy dispersive X-ray spectroscopy (EDS) data. To explore the effect of cobalt oxide formation on the magnetic properties of CoPt NPs a variable temperature $9 \mathrm{~T}$ Quantum Design physical property measurement system (PPMS) with a vibrating sample magnetometer (VSM) system was used for $M-T$ (at zero field cooled, ZFC, and field cooled, FC) and $M-H$ field measurements at $5 \mathrm{~K}, 60 \mathrm{~K}$ and $300 \mathrm{~K}$ under $\pm 5 \mathrm{~T}$ field.

\section{Results}

Figure 1 shows x-ray diffraction (XRD) data (black circle) and Rietveld refinements (solid red line) for as-prepared CP-Ar and CP-Air NPs. The peaks at $2 \theta=40.4^{\circ}, 47.1^{\circ}, 68.7^{\circ}, 82.8^{\circ}$ and $87.4^{\circ}$ for both samples correspond to the (111), (200), (220), (311) and (222) lattice planes of cubic phase [20], respectively. As seen in Figure 1, both samples are produced with high purity by polyol method. However, Figure 1(b) reveals additional peaks due to cobalt oxide formation in the CP-Air sample structure. The peak at $2 \theta=31^{\circ}$ belongs to $\mathrm{Co}_{2} \mathrm{O}_{3}$ formation $[21,22]$ and the peaks at $2 \theta=43.9^{\circ}$, and $50.9^{\circ}$ correspond to cobalt oxide formation on the CoPt structure [23]. This reveals that the oxide formation is only possible under air condition. To explore lattice constant $(a)$, lattice angle $(\alpha)$, unit cell volume $(V)$, and Bragg positions of the samples (see Figure 1), we were carried out Rietveld refinements of XRD data using Full Prof software. We investigated the crystalline symmetry as the $F m \overline{3} m$ (JCPDS: 15-0806) space groups of fcc-Co cubic phases for both samples from the simulation [24]. The lattice constants were found to be $3.86 \AA$ and $3.88 \AA$ for the samples prepared under Ar pressure and air, respectively [25]. The $d_{(111)}$ spacing is calculated via Rietveld refinement and found to be $2.23 \AA$ and $2.24 \AA$ for CP-Ar and CP-Air NPs, respectively. These slight shifts of the lattice constant and the spacing might be due to the oxygen formation in the CP-Air sample structure. Scherrer's equation is used to calculate the average size of the single crystalline domain, $D_{p}(\mathrm{~nm})$ for both samples which are presented in Figure 1. The crystalize sizes are calculated as $3.80 \mathrm{~nm}$ and $5.05 \mathrm{~nm}$ for CP-Ar and CP-Air NPs, respectively. This increase is due to cobalt-oxide formation in the structure. 

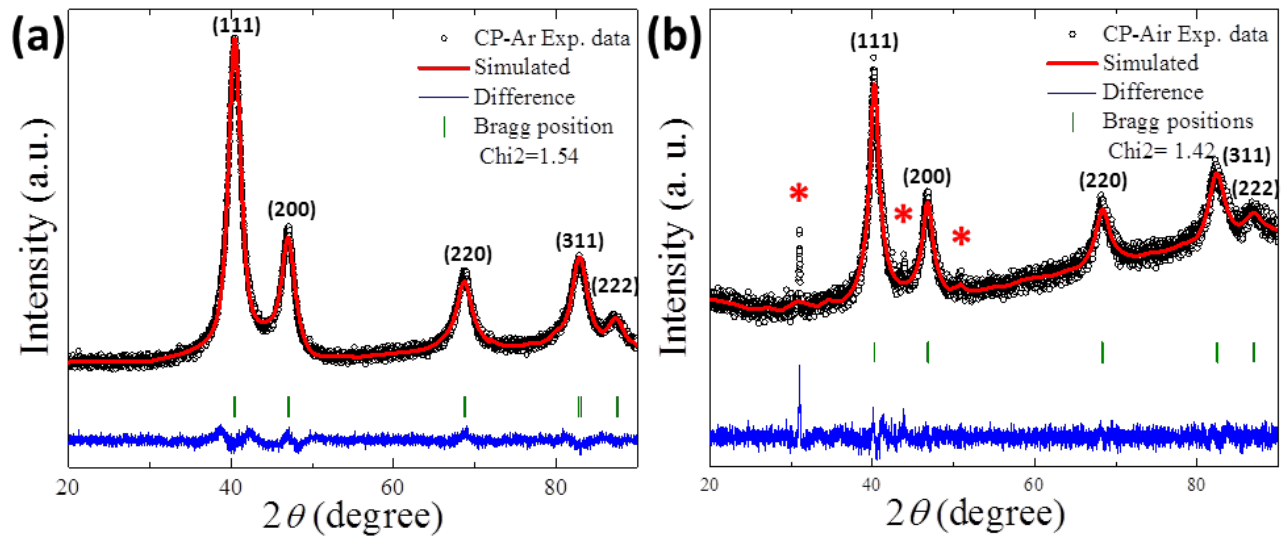

Figure 1: (a-b) XRD patterns (black circle) of cobalt oxide on CoPt NPs under Ar gas and Air, respectively, after Rietveld refinement which provide simulated data (solid red line), differences (solid blue line), and Bragg positions (green bar) with low Chi2. (*) show cobalt-oxide formations

Table 1: Agreement factor $(\chi)$, lattice constant $(a)$, lattice angle $(\alpha)$, and unit cell volume $(V)$ of cobalt oxide on CoPt NPs are obtained after Rietveld refinement. XRD peak widths are used to calculate the crystallite size $\left(D_{p}\right)$ by the Scherrer formula. Several SEM images are investigated for the average particle size

\begin{tabular}{cccccc}
\hline Sample & $\chi^{\mathbf{2}}$ & $\boldsymbol{a}=\boldsymbol{b}=\boldsymbol{c}(\boldsymbol{\AA})$ & $\begin{array}{c}\boldsymbol{V} \\
\left(\AA^{3}\right)\end{array}$ & $\begin{array}{c}\text { Crystallite size } \\
\boldsymbol{D}_{\boldsymbol{p}}(\mathbf{n m})\end{array}$ & $\begin{array}{c}\text { Average particle Size } \\
(\mathbf{n m})\end{array}$ \\
\hline $\mathbf{C o P t}_{1.12} \mathbf{O}_{\mathbf{1 . 9 3}}$ Under $\mathbf{A r}$ & 1.54 & 3.8627 & 57.63 & $3.80 \pm 0.43$ & $7.92 \pm 0.052$ \\
$\mathbf{C o P t}_{1.24} \mathbf{O}_{3.4}$ Under Air & 1.42 & 3.8812 & 58.46 & $5.05 \pm 0.41$ & $5.99 \pm 0.039$ \\
\hline
\end{tabular}

Air-stable nanoparticle imaging has been performed with SEM technique which revealed monodisperse particle distribution for the samples. Figure 2(a-b) show CP-Ar and CP-Air samples formation with a 400000x and 500000x magnifications, respectively. We observed NPs distributed on the surface without adhesion due to the successful process the covering NPs with oleic acid and oleylamine surfactants. Some areas in Figure 2(b) without nanoparticles correspond to possible cobalt oxide formation which results in the disappearance of the NPs in the area. Figure 2(c-d) show the number of particles vs. particle size histogram that were fitted with the log-normal distribution (solid blue line). By fitting, the average particle sizes found to be $7.92 \mathrm{~nm}$ and 5.99 $\mathrm{nm}$ with narrow size distribution for CP-Ar and CP-Air samples (see Figure 2), respectively. We were calculated the compound stoichiometry via averaged weight and atomic percentages EDS data from five different areas which were averaged as C:55.67, O:21.13, Co:10.93 and Pt:12.28 for CP-Ar and C:50.90, O:29.63, Co:8.69 and Pt:10.78 for CP-Air samples. In the first phase, we obtained $\mathrm{CoPt}_{2.3}$ NPs. Adding only Co under Ar gas and air conditions resulted in $\mathrm{CoPt}_{1.12} \mathrm{O}_{1.93}$ and $\mathrm{CoPt}_{1.24} \mathrm{O}_{3.4}$ compounds, respectively. The EDS stoichiometric calculation is also showed that producing in the air led to more cobalt oxide formation in the sample. 

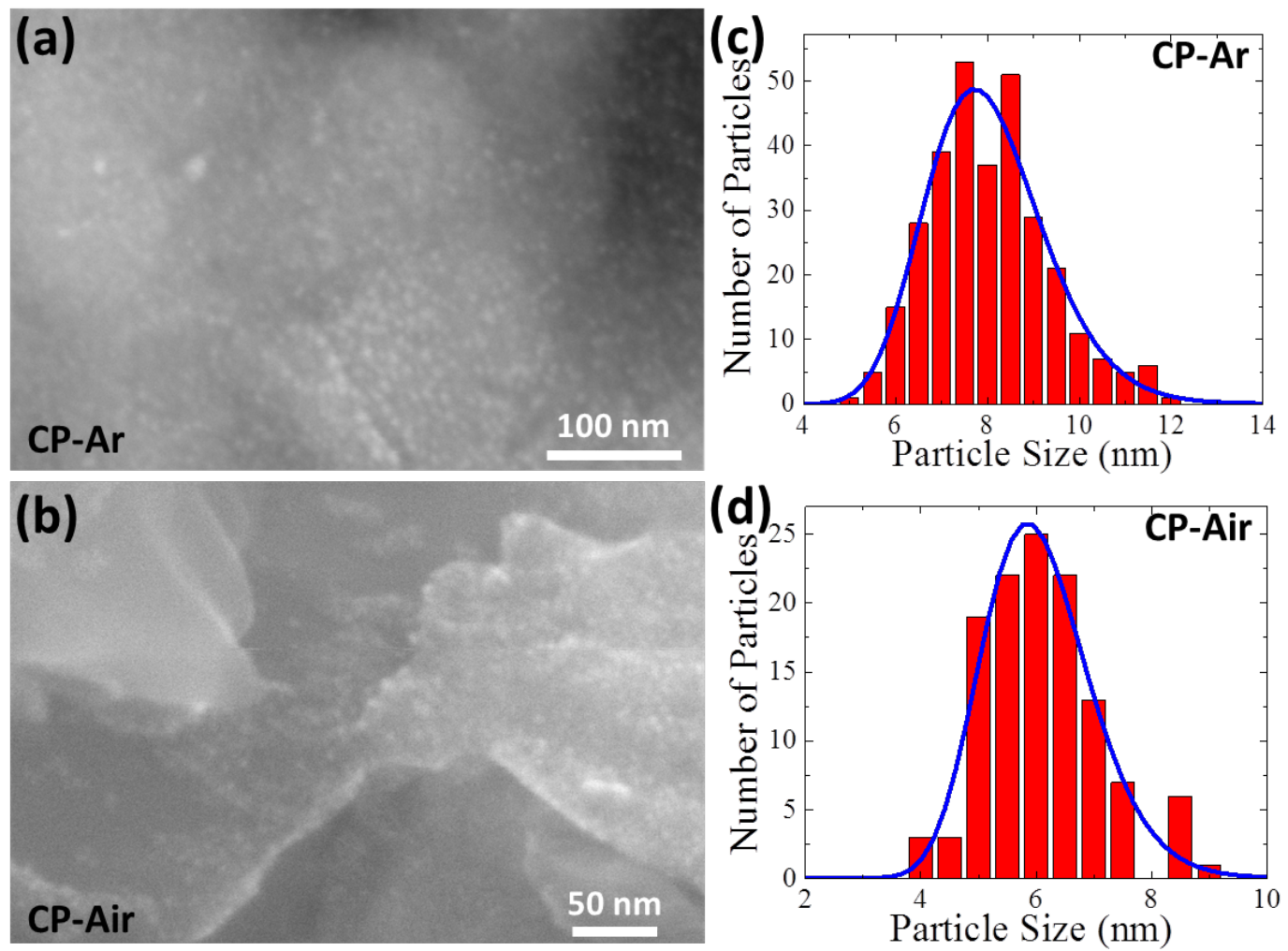

Figure 2: (a-b) SEM images of CP-Ar and CP-Air NPs. (c-d) The average particle size (red bar) distributions fitted by a log-normal distribution (solid blue line) inset plot for both samples

To investigate the effect of the oxidation process on the magnetic properties, we first measured zero-field cooled (ZFC) and field-cooled (FC) cycles for CP-Ar (black) and CP-Air (red) nanoparticles between $5 \mathrm{~K}$ and $300 \mathrm{~K}$ with applying 500 Oe external field. We observed typical ferromagnetic signal at low temperature for both samples (see Figure 3(a)). Well defined maximum of ZFC curve exhibits a superparamagnetic blocking temperature, $T_{B}$, for $\mathrm{CP}-\mathrm{Ar}$ and CP-Air samples which are about $60 \mathrm{~K}$ and $28 \mathrm{~K}$, respectively. These sharp decreases are usually observed when the particles exhibit uniform distribution [26]. Besides, increasing particle size results in an increase in $T_{B}$ due to increased anisotropy in the structure. We observed from XRD and $M-T$ data that there is no cobalt-oxide formation in CP-Ar sample which has a similar behaviour temperature-dependent magnetization curve and $T_{B}$ with earlier findings $[26,27]$. Once, the cobalt oxide layer is formed on CoPt particles, the ferromagnetic signal in the CP-Air sample is reduced due to $\mathrm{CoO}$ antiferromagnetic contribution.

The hysteresis loops of CP-Ar (black) and CP-Air (red) samples are shown in Figure 3(bd) at $5 \mathrm{~K}, 60 \mathrm{~K}$ and $300 \mathrm{~K}$ by applying a $\pm 5 \mathrm{~T}$ magnetic field. While a strong ferromagnetic signal is observed for CP-Ar (black) particle at $5 \mathrm{~K}$, the superparamagnetic signal became dominant with losing the hysteresis at $60 \mathrm{~K}$ and $300 \mathrm{~K}$ which are above $T_{B}$ for both samples. The hysteresis loops could not be saturated at any temperature up to $\pm 5 \mathrm{~T}$ applied field. We summarized the calculated 
values of blocking temperature $\left(T_{B}\right)$, coercive field $\left(H_{c}\right)$, exchange bias $\left(H_{E B}\right)$, and remanent magnetization $\left(M_{R}\right)$ at $5 \mathrm{~K}$ for CP-Ar and CP-Air NPs in Figure 3. CP-Ar and CP-Air exhibit relatively large $H_{c}$ about $1021 \mathrm{Oe}$ and $421 \mathrm{Oe}$ at $5 \mathrm{~K}$, respectively. Above $T_{B}, H_{c}$ has vanished due to a shift from ferromagnetic state to superparamagnetic state. Similar values are calculated for samples that exhibit relatively low $93 \mathrm{Oe}$ and $8 \mathrm{Oe}$ of $H_{E B}$, at $5 \mathrm{~K}$ and there is no $H_{E B}$ at $60 \mathrm{~K}$ and $300 \mathrm{~K}$. This is probably because ferromagnetic-paramagnetic CoPt does not interact with antiferromagnetic $\mathrm{CoO}$ layer.

Table 2: Blocking temperature $\left(T_{B}\right)$, coercive field $\left(H_{c}\right)$, exchange bias $\left(H_{E B}\right)$, and remanent magnetization $\left(M_{R}\right)$ for CP-Ar and CP-Air NPs measured at $5 \mathrm{~K}$

\begin{tabular}{|c|c|c|c|c|}
\hline Sample & $T_{B}(\mathrm{~K})$ & $H_{c}(\mathrm{Oe})$ & $H_{E \mathrm{~B}}(\mathrm{Oe})$ & $M_{R}(\mathrm{emu} / \mathrm{g})$ \\
\hline $\mathrm{CoPt}_{1.12} \mathrm{O}_{1.93}$ Under Ar & 60 & $1021 \pm 10.2$ & $93 \pm 0.9$ & 3.47 \\
\hline $\mathrm{CoPt}_{1.24} \mathrm{O}_{3.40}$ Under Air & 28 & $421 \pm 4.2$ & $8 \pm 0.1$ & 2.4 \\
\hline
\end{tabular}

We calculate the uniaxial anisotropy constant, $K_{u}$, as a function of particle volume, $V$, by: $T_{B}=K_{u} V / 25 k_{B}$ where $k_{B}$ is the Boltzmann constant $\left(1.38 \times 10^{-16} \mathrm{erg} / \mathrm{K}\right)[27,28]$. The maximum moment value is found as $8.02 \times 10^{5} \mathrm{erg} / \mathrm{cm}^{3}$ and $8.54 \times 10^{5} \mathrm{erg} / \mathrm{cm}^{3}$ for CP-Ar and CP-Air NPs, respectively. These are similar to earlier report of CoPt NPs as $1.0 \times 10^{6} \mathrm{erg} / \mathrm{cm}^{3}$ for the blocking temperature of $60 \mathrm{~K}$ [29]. An effective magnetic moment, $\mu_{\text {eff }}$ is a value of the magnitude of the paramagnetism in the CoPt due to Pt. We can calculate moment by $\mu_{\text {eff }}=\left(M M_{S}\right) /\left(N_{A} \beta\right)$. Here, $M$ is the molecular weight of samples, $M_{S}$ is saturation magnetization of sample, $N_{A}$ is the Avogadro's number and $\beta$ is the conversion factor that is $9.27 \times 10^{-21} \mathrm{erg} / \mathrm{Oe}$. The samples did not exhibit full saturation however we were taken into account the maximum magnetization for CP-Ar and CPAir NPs with $\pm 5 \mathrm{~T}$ external field at $5 \mathrm{~K}$ and we calculated $\mu_{\text {eff }} 0.70 \mu_{B}$ and $1.21 \mu_{B}$, respectively. So, the paramagnetic effect is in CP-Air NPs increased with the increased ratio of Pt in the compound. 

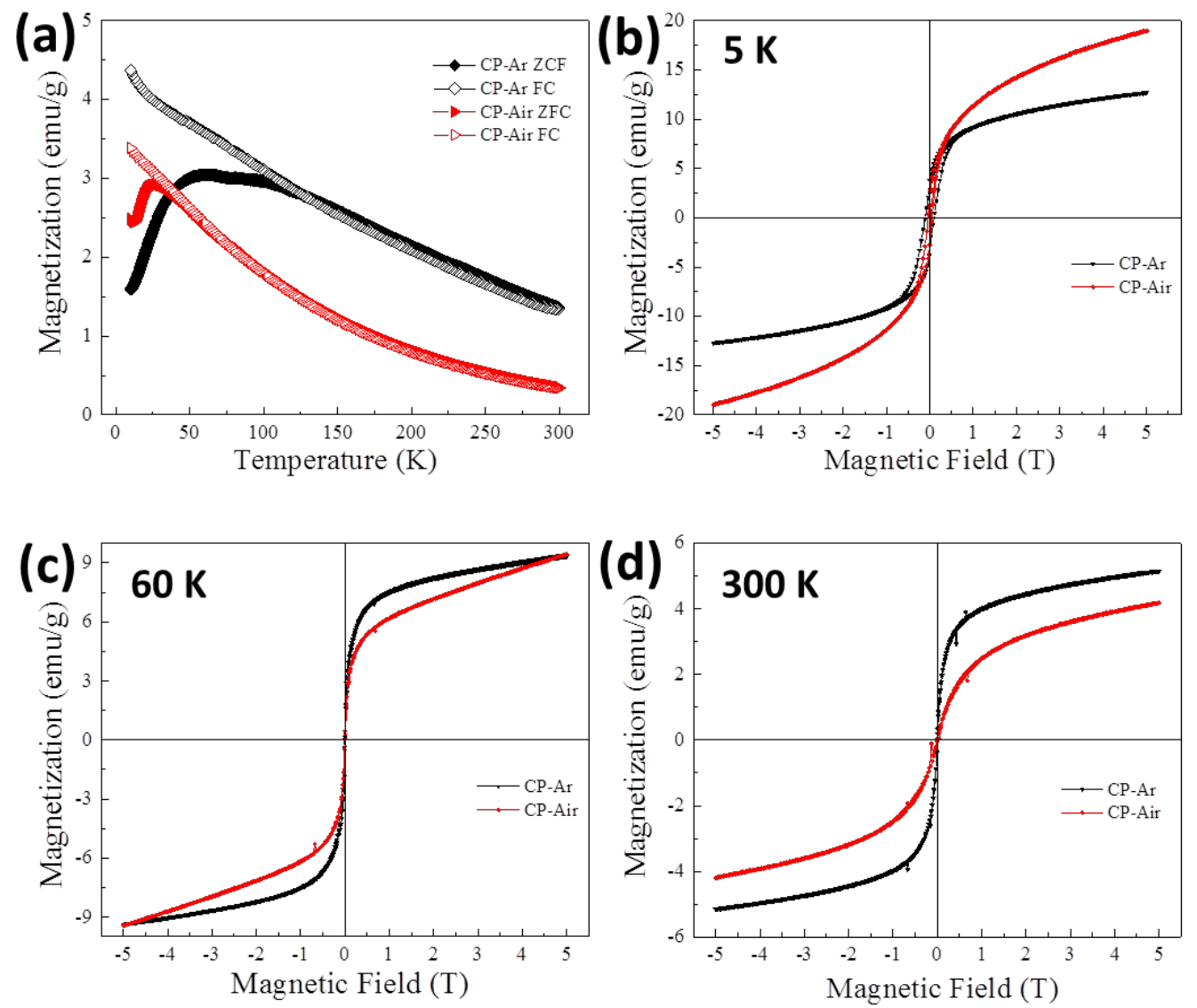

Figure 3: (a) Zero-field cooled (ZFC) and field-cooled (FC) cycles for CP-Ar (black) and CP-Air (red) nanoparticles between $5 \mathrm{~K}$ and $300 \mathrm{~K}$. (b-d) Magnetic hysteresis loops of CP-Ar (black) and CP-Air (red) NPs measured at $5 \mathrm{~K}, 60 \mathrm{~K}$ and $300 \mathrm{~K}$, respectively

The magnetization of samples increased from $5 \mathrm{emu} / \mathrm{g}$ at $300 \mathrm{~K}$ to $19 \mathrm{emu} / \mathrm{g}$ at $5 \mathrm{~K}$ with an applied field of $\pm 5 \mathrm{~T}$. However, the $5 \mathrm{~T}$ field remain incapable to saturate both samples due to the large particle size in the samples. The remanent magnetizations, $M_{R}$, of samples are found to be $3.47 \mathrm{emu} / \mathrm{g}$ and $2.4 \mathrm{emu} / \mathrm{g}$ for CP-Ar and CP-Air samples, respectively. We observed zero $M_{R}$ at $60 \mathrm{~K}$ and $300 \mathrm{~K}$ due to the paramagnetic signal overcomes the ferromagnetic signal of CoPt NPs above $T_{B}$. Although oxidation process highly effective method to produce chemically and thermally stable the NPs, the effect of oxidation results in reduce in magnetic properties such as $T_{B}, H_{c}, H_{E B}$, and the effective magnetic moment. The ferromagnetic origin at room temperature is due to uncompensated surface spins with uncompensated spins. These spins strongly coupled to the $\mathrm{CoO}$ antiferromagnetic layer which is usually observed small NPs less than $10 \mathrm{~nm}$ [30]. Below the blocking temperature the magnetization of $\mathrm{CP}$-Air sample increase as expected.

\section{Conclusions}

In summary, we have prepared the addition of Co on CoPt nanoparticles under argon gas and in the air environment. XRD results showed that there are three additional peaks of oxide 
formation in the CP-Air sample. The SEM images revealed that the average particle sizes are less than $8 \mathrm{~nm}$ which is important for practical applications. Besides reasonable high coercive field, exchange bias, and remanent magnetization were obtained at $5 \mathrm{~K}$, above blocking temperature all these vanishes due to dominant paramagnetic signal in the sample structure. We can also conclude that the cobalt oxide formation does not interact with CoPt samples. Although the samples exhibit an increase in saturation magnetization with decreasing temperature, in order to reach total saturation more than $\pm 5 \mathrm{~T}$ external field is required. The effect of the $\mathrm{CoO}$ thickness on the $\mathrm{CoPt}$ core remains a major problem for nanoparticles and require further study with high-resolution imaging techniques.

\section{Acknowledgement}

The authors acknowledge support from Cukurova University, Adana, Turkey, under Scientific Research Funding Grand No: FBA-2018-10412.

\section{References}

[1] Ethirajan, A., Wiedwald, U., Boyen, H.-G., Kern, B., Han, L., Klimmer, A., Weigl, F., Kästle, G., Ziemann, P., Fauth, K., Cai, J., Behm, R.J., Romanyuk, A., Oelhafen, P., Walther, P., Biskupek, J. and Kaiser, U., A Micellar Approach to Magnetic Ultrahigh-Density Data-Storage Media: Extending the Limits of Current Colloidal Methods, Advanced Materials (Weinheim, Germany), 19(3), 406-410, 2007.

[2] Plumer, M.L., Van Ek, J. and Weller, D., The physics of ultra-high-density magnetic recording, Springer Science \& Business Media, 2012.

[3] Weller, D., Moser, A., Folks, L., Best, M.E., Wen, L., Toney, M.F., Schwickert, M., Thiele, J. and Doerner, M.F., High Ku materials approach to 100 Gbits/in2, IEEE Transactions on Magnetics, 36(1), 10-15, 2000.

[4] Himpsel, F., Ortega, J., Mankey, G. and Willis, R., Magnetic nanostructures, Advances in physics, 47(4), 511-597, 1998.

[5] Jiles, D., Introduction to magnetism and magnetic materials, CRC press, 2015.

[6] Alloyeau, D., Ricolleau, C., Mottet, C., Oikawa, T., Langlois, C., Le Bouar, Y., Braidy, N. and Loiseau, A., Size and shape effects on the order-disorder phase transition in CoPt nanoparticles, Nature Materials, 8, 940, 2009.

[7] Barmak, K., Kim, J., Lewis, L.H., Coffey, K.R., Toney, M.F., Kellock, A.J. and Thiele, J.-U., On the relationship of magnetocrystalline anisotropy and stoichiometry in epitaxial L1, CoPt (001) and FePt (001) thin films, Journal of Applied Physics, 98(3), 033904, 2005.

[8] Chen, Q., Qin, Z., Gan, Q., Xinqi, C., Hai, W., Daming, S., Bixiao, W., Lifeng, X. and Yiwen, T., Designing 3D interconnected continuous nanoporous $\mathrm{Co} / \mathrm{CoO}$ core-shell nanostructure electrodes for a high-performance pseudocapacitor, Nanotechnology, 28(8), $085401,2017$.

[9] Lin, J., Zhou, W., Kumbhar, A., Wiemann, J., Fang, J., Carpenter, E.E. and O'Connor, C.J., Gold-coated Iron (Fe@Au) nanoparticles: Synthesis, characterization, and magnetic fieldinduced self-assembly, Journal of Solid State Chemistry, 159(1), 26-31, 2001. 
[10] Mori, K., Kondo, Y. and Yamashita, H., Synthesis and characterization of FePd magnetic nanoparticles modified with chiral BINAP ligand as a recoverable catalyst vehicle for the asymmetric coupling reaction, Physical Chemistry Chemical Physics, 11(39), 8949-8954, 2009.

[11] Wu, N., Fu, L., Su, M., Aslam, M., Wong, K.C. and Dravid, V.P., Interaction of fatty acid monolayers with Cobalt nanoparticles, Nano Letters, 4(2), 383-386, 2004.

[12] Chen, M. and Nikles, D.E., Synthesis of spherical FePd and CoPt nanoparticles, Journal of Applied Physics, 91(10), 8477-8479, 2002.

[13] Sobal, N.S., Ebels, U., Möhwald, H. and Giersig, M., Synthesis of Core-Shell PtCo Nanocrystals, Journal of Physical Chemistry B, 107(30), 7351-7354, 2003.

[14] Gopinath, S., Sivakumar, K., Karthikeyen, B., Ragupathi, C. and Sundaram, R., Structural, morphological, optical and magnetic properties of $\mathrm{Co}_{3} \mathrm{O}_{4}$ nanoparticles prepared by conventional method, Physica E: Low-dimensional Systems and Nanostructures, 81, 66-70, 2016.

[15] Liang, Y., Li, Y., Wang, H., Zhou, J., Wang, J., Regier, T. and Dai, H., $\mathrm{Co}_{3} \mathrm{O}_{4}$ nanocrystals on graphene as a synergistic catalyst for oxygen reduction reaction, Nature Materials, 10(10), 780-786, 2011.

[16] Shatrova, N., Yudin, A., Levina, V., Dzidziguri, E., Kuznetsov, D., Perov, N. and Issi, J.-P., Elaboration, characterization and magnetic properties of cobalt nanoparticles synthesized by ultrasonic spray pyrolysis followed by hydrogen reduction, Materials Research Bulletin, 86, 80-87, 2017.

[17] Izu, N., Matsubara, I., Uchida, T., Itoh, T. and Shin, W., Synthesis of spherical cobalt oxide nanoparticles by a polyol method, Journal of the Ceramic Society of Japan, 125(9), 701704, 2017.

[18] Salavati-Niasari, M., Khansari, A. and Davar, F., Synthesis and characterization of cobalt oxide nanoparticles by thermal treatment process, Inorganica Chimica Acta, 362(14), 4937-4942, 2009.

[19] Sinkó, K., Szabó, G. and Zrínyi, M., Liquid-phase synthesis of cobalt oxide nanoparticles, Journal of Nanoscience and Nanotechnology, 11(5), 4127-4135, 2011.

[20] Sun, X., Jia, Z., Huang, Y., Harrell, J., Nikles, D., Sun, K. and Wang, L., Synthesis and magnetic properties of CoPt nanoparticles, Journal of Applied Physics, 95(11), 6747-6749, 2004.

[21] Aksoy Akgul, F., Akgul, G. and Kurban, M., Microstructural properties and local atomic structures of cobalt oxide nanoparticles synthesised by mechanical ball-milling process, Philosophical Magazine, 96(30), 3211-3226, 2016.

[22] Wang, X., Ge, H., Ye, Q., Si, P. and Chen, H., Weak Ferromagnetism and Exchange Bias in Antiferromagnetic Cobalt Oxide Nanoparticles, Journal of Magnetics, 23(4), 487-490, 2018.

[23] Qiu, B., Guo, W., Liang, Z., Xia, W., Gao, S., Wang, Q., Yu, X., Zhao, R. and Zou, R., Fabrication of $\mathrm{Co}_{3} \mathrm{O}_{4}$ nanoparticles in thin porous carbon shells from metal-organic frameworks for enhanced electrochemical performance, RSC advances, 7(22), 13340-13346, 2017.

[24] Liu, Y., Yang, Y., Zhang, Y., Wang, Y., Zhang, X., Jiang, Y., Wei, M., Liu, Y., Liu, $\mathrm{X}$. and Yang, J., A facile route to synthesis of CoPt magnetic nanoparticles, Materials Research Bulletin, 48(2), 721-724, 2013. 
[25] Trung, T.T., Nhung, D.T., Nam, N.H. and Luong, N.H., Synthesis and Magnetic Properties of CoPt Nanoparticles, Journal of Electronic Materials, 45(7), 3621-3623, 2016.

[26] San, B.H., Lee, S., Moh, S.H., Park, J.-G., Lee, J.H., Hwang, H.-Y. and Kim, K.K., Size-controlled synthesis and characterization of CoPt nanoparticles using protein shells, Journal of Materials Chemistry B, 1(10), 1453-1460, 2013.

[27] Tournus, F., Tamion, A., Blanc, N., Hannour, A., Bardotti, L., Prével, B., Ohresser, P., Bonet, E., Epicier, T. and Dupuis, V., Evidence of L1 $1_{0}$ chemical order in CoPt nanoclusters: Direct observation and magnetic signature, Physical Review B, 77(14), 144411, 2008.

[28] Frommen, C., Malik, S., Würfel, J.U., Rösner, H. and Didschies, C., Synthesis and magnetic properties of CoPt 3 nanoparticle assemblies containing copper, Materials Letters, 58(6), 953-958, 2004.

[29] Rooney, P.W., Shapiro, A.L., Tran, M.Q. and Hellman, F., Evidence of a SurfaceMediated Magnetically Induced Miscibility Gap in Co-Pt Alloy Thin Films, Physical Review Letters, 75(9), 1843-1846, 1995.

[30] Dai, Q. and Tang, J., The optical and magnetic properties of CoO and Co nanocrystals prepared by a facile technique, Nanoscale, 5(16), 7512-7519, 2013. 